\title{
Dividuated selves: on Renaissance criticism, critical finitude and the experience of ethical subjectivity
}

\author{
John J. Joughin \\ University of Central Lancashire
}

\begin{abstract}
This paper situates the work of Renaissance criticism as a type of belated work of mourning or memorial aesthetics. In particular I want to focus on the emergence of a supposedly "modern" form of subjectivity during the theorisation of Renaissance criticism in the eighties -its distinctiveness as well as its occlusions. For the purpose of this essay I take the work of the British critic Francis Barker as, in some sense, broadly representative of a trend in political criticism that was focused on a recovery of the lost significance of the body as a site of subjection. However, I will also argue that the relocation of the mind-body split in the first wave theorisation of Renaissance criticism needs to be read again. The founding dividuation of self in this early criticism is now often criticised for positioning the subject in reductively functionalist or mechanistic terms, as the product of the discourse of power/knowledge that produced it. However, in much of the work that we label cultural materialist or new historicist, the experience of dualism also secreted an ethical standpoint that is worthy of our re-evaluation. In particular, and in building on the insights of Gillian Rose and Judith Butler on mourning, I suggest that the lyrical contemplation of lost bodies in radical criticism implicates our ties to others, as well as the relational ties to others implicit in any political sense of community. In turn, this suggests a more sophisticated account of political subjectivity, as well as a potential reparation of the concept of a political self for radical criticism.
\end{abstract}

KEYWORDS: memorial aesthetics, mourning, finitude, subjectivity, Shakespeare, cultural materialism.

(c) ederit 19 (2009): 45-69

https://doi.org/10.34136/sederi.2009.3 


\section{J.J. Joughin}

\section{Introduction}

Strikingly, in any number of philosophical and literary texts, the contemplation of finitude -the condition of life as brutish and short and without any necessary or transcendent promise of salvation or afterlife- simultaneously marks a form of lyrical intensity for those who experience it. During the early modern period, in an increasingly secular modernity, for poets, philosophers and artists alike, the contemplation of a bounded, limited or transient self demands a response that could be characterised as "aesthetic" insofar as art is still tied to a form of sensory encounter with the world and thereby becomes a type of "placeholder" for the embodiment of that experience which is now also under threat. ${ }^{1}$

In René Descartes' Meditations on First Philosophy for example, the instantiation of an experience that is formative in its insistence of a mind-body split (between the self and the world), simultaneously calls forth images of ruination, or "self-annihilation", which casts the story of modernity in terms that anticipate the opening of a gothic romance:

I will suppose therefore that not God, who is supremely good and the source of truth, but rather some malicious demon of the utmost power and cunning has employed all his energies in order to deceive me. I shall think that the sky, the air, the earth, colours, shapes, sounds and all external things are merely the delusions of dreams which he has devised to ensnare my judgement. I shall consider my self as not having hands or eyes, or flesh, or blood or senses, but as falsely believing that I have all these things [...]. I shall have to toil not in the light, but amid the inextricable darkness of the problems I have now raised. (1986: 15)

Considered in this light, Descartes' famous instantiation of a disembodied thinking self -"I shall consider myself as not having hands or eyes, or flesh, or blood or senses"- could just as easily be juxtaposed with Mary Shelley's later reinvention of the human in Frankenstein. In short, it as if Cartesian dualism announces itself as a type of "exemplary horror tract" -an experiment bound to be repeated but best not imitated. ${ }^{2}$ And it is in precisely these equivocal

\footnotetext{
${ }^{1}$ A claim that arguably reaches its culmination in modernist aesthetics. For a fuller account to which I am indebted here $c f$. Jay Bernstein (2006, esp. 1-45).

${ }^{2}$ I owe this reading of Descartes and the point that follows to Thomas Docherty. As he rightly observes: "It is this presentation of the philosophy as a kind of horror-tract that
} 
terms, that Descartes warns us that: "The simple resolve to strip oneself of all opinions and beliefs formerly received is not to be regarded as an example that each man should follow [...] like one who walks alone in the twilight I resolved to go slowly" (quoted in Docherty 1996: 483). Descartes' sceptical attempt to inaugurate modern subjectivity "o'ercrows the spirit", or darkens proceedings, or is at the very least marked by trepidation and by a human body trembling or indeed merely tremulous.

If philosophers philosophise only in terror in their anticipation of the horrors of modern identity, then, in turn, modern artworks could also be said to authenticise their claim to validity only by "giving us a glimpse of the truth of finitude." ${ }^{3}$ As such my second opening takes its cue from Holbein's depiction of Christ Entombed (1522). Unlike the more conventional Italianate altarpieces that appeared throughout the Renaissance which idealised a just proportion between a divine and natural order of things; Holbein's radically "horizontal" take on death is, in some sense, as Jay Bernstein argues, a precursor of "painterly realism" and confirms an emergently secular imagination in "its severing of the dead body from even the thought of transcendence" (2006: 42). The tomb in Holbein's painting is visibly open and we are invited to look at the work that death is doing. The vulnerability of the flesh firmly earthbound -finite and dematerialising before our eyes, so that, as John Carroll points out:

Holbein kills Christ by demolishing the crucifixion. His Christ is no more than a dead body. It lies, life-size, inside the grave. We look in from the side and around the wounds in the visible foot, hand and side the flesh is black-green with decay. The dried-out hair and beard is jutting brittle black. The skeletal right hand, the hand of authority, is stiff with rigor mortis, the middle finger elongated and pressing down on the stone slab like a dead twig $[\ldots]$. The expression on the face is one of horror, the mouth open, the white of the visible eye enlarged. This man died a gruelling death and in his last moments there was no peace or radiance, just the sheer terror of the pain and nothing beyond. (1993: 33)

makes it exciting and, despite Descartes proclamations to the contrary, exemplary" (Docherty 1996: 483).

${ }^{3}$ I owe the expression to Simon Critchley (2007). 


\section{J.J. Joughin}

In Holbein's Ambassadors, the absent presence of an anamorphic skull allows a temporary sense of our viewing mastery, only to heighten our awareness of the unstable border between life and death. In Christ Entombed, the side view of the tomb provides the viewer with another asymmetrical view -this time between viewer and sacrificial victim- though once again only in the acknowledgement that separateness is the unity of our condition. Importantly, as Carroll reminds us, there is "no serene smile of redemption" in Holbein's representation of Christ:

What we see is rot and shrinkage, no different from a dead fish washed up on the beach. This man did not rise from the grave. There was no resurrection. Flesh is flesh, which means festering wounds, stiffening joints and the stench of decomposition. Death is death. The Christ Corpse has uncanny force [...]. No one can escape the elongated, bony middle finger of Holbein's Christ, as it collapses downwards on the stone slab -the new world is empty of authority. Mortality rules. (Carroll 1993: 33-34)

In summary, one might say that Descartes and Holbein track two of the most influential trajectories for later modernity. If the dissolution of self mapped by Cartesian subjectivity eventually locates the disembodied rationality which results in the scientific abstraction of the Enlightenment, then Holbein's "painterly realism" arguably configures an increasingly displaced and removed future for artworks -their transient particulars doubling as a mere residue of the meaningful loss produced by the loss of transcendent meaning. These two cultures of modernity -science versus art- each in their own way then make a merit of finitude. Yet, in the process, any attempt to shape, delineate and define the world is betrayed by mortification and alienation. In short, finitude constitutes an inextricable double-bind in producing meaning on the one hand only to confirm our own mortal limitations on the other. As a result, our knowledge of the world is almost inevitably cast as melancholic -tied to an experience of "not knowing" and in the same process making an "enigmatic" virtue of our vulnerability and loss. ${ }^{4}$

\footnotetext{
${ }^{4}$ I am indebted to Judith Butler for this insight, see her account of Precarious Life: The Powers of Mourning and Violence (2006) to which I return below and cf. esp. 22.
} 


\section{Critical finitude ${ }^{5}$}

This recognition of the "radical finitude" of the modern human subject, "i.e. that there is no God-like standpoint or point of reference outside of human experience from which the latter might be characterised and judged" (Critchley 1998: 10), was very much part of the radicalisation of Renaissance studies during the eighties, which was quick enough to locate the invention of the human as the unstable fiction that it actually is. In its acknowledgement of the contingency of human experience a dislodgement of the self was at the heart of a range of ground-breaking texts that introduced literary theory to Renaissance criticism, so that Jonathan Dollimore's Radical Tragedy (1984), Catherine Belsey's The Subject of Tragedy (1985) Stephen Greenblatt's Renaissance Self-fashioning (1980) and Francis Barker's The Tremulous Private Body (1984) -each, in some part, constituted essays on the history of subjection that refused the dogmatic fixities of the past. Yet, in critiquing the conditions of modern subjectivity and opposing the inscription of the self "as an object of rational knowledge", cultural materialism and new historicism placed an emphasis on the negation of the self without weighing the consequence of this event reflectively enough. As such, even the most trenchant of the political criticism of the eighties remains alive to the transformative potential of Renaissance literature and its capacity to produce affects and meanings that question or unsettle our critical expectations, without then construing fully the implication of its own reading experience. I would want to argue that these readings were often unwittingly proto-aestheticist insofar as key paradigm shifts within cultural criticism are clearly themselves indirectly reliant on the transformative cognitive potential of the aesthetic. As a result, in the process of transgressively "overcoming the self", for many critics, a certain lyrical singularity accrues from the inevitable 'proximity' of death and thinking. Here, for example, is Francis Barker speaking of

\footnotetext{
5 Critical finitude? My subtitle actually takes its cue from the contemporary philosopher Richard Rorty, whose critical stance I do not share, but who in speaking to the extremity of our situation nevertheless offers an acute diagnosis of the predicament I want to interrogate further here. So that, as Rorty observes: "[T]he problem of how to finitize while exhibiting a knowledge of one's own finitude [...] is the problem of ironist theory. It is the problem of how to overcome authority without claiming authority" (1989: 104-105 as cited in Bowie 1997: 86).
} 
the emergence of the private body -an emergence that, perhaps in homage to Descartes, remains "tremulous" and enigmatic:

The scene of writing and of reading, is, like the grave, a private place. We must explore the contents of this privacy, in relation to what is publicly speakable, and draw the diagram of the structure of confessions and denials of desire that gives this passage its peculiar numinosity, and, in principle, as a representative, a special place in history of the bourgeois soul.

In Pepys' chamber, unlike the quiet tomb in which the dismembered but visible body of Marvell's beloved was recently interred, if not echoing sounds, at least ghostly mutterings can indeed be heard, rustling among the feints and side-steps of the text's involuted speech. (1984: 3-4)

For Barker, the intensity of the spectre of the dissolution of the self (and the impossibility of embracing the other) is palpable and poignant. More than most, his work endlessly returns to the ruinous excess exacted by the allegorisation of the body, or rather the incorporeal entity of its vanishing point -"numinous", dismembered but still (barely) visible "beneath the winding sheet." 6

Such readings necessarily bear witness to the critic as insomniac -one who gleans his ungraspable remainder from an unquiet tomb. Barker sets the scene of writing and reading and immediately remarks a work of mourning and incompletion. The hermeneutic yield of such moments and the scenes of suffering that follow lies, in no small part, in their refusal of the negation afforded by the "informational reading" that might make sense of it ("the history of the bourgeois soul" here represented by Pepys the navy clerk) and opens instead on to what Blanchot would term a responsiveness to what is "other than knowledge" (Haase and Large 2001: 55) -that which remains secret or at least not yet "publicly speakable." Here, as elsewhere in Barker's work (but perhaps this is the exemplary instance), the critical self, in this case the one who writes and reads, is cast as interrupted, exposed and responsive (despite itself) to an

\footnotetext{
${ }^{6}$ One is reminded here of Maurice Blanchot for whom, as Ullrich Haase and William Large remind us, the reading experience is in part a process which "beneath the winding sheet .... like the secret of the tomb itself, refuses our grasp" see Haase and Large (2001: 14).
} 
"excessive demand that calls into question the dominance of the subject." 7

In other words the self is "dividuated" -in the Pepysian instance case riven, by a sexuality or desire that can no longer be frankly avowed. Moreover, this sense of dividuation is, I would want to argue, following Simon Critchley, precisely at the heart of the experience which determines an ethical subjectivity, so that, as Critchley recently reminds us:

The ethical subject is [...] hetero-affectively constituted. It is a split subject divided between itself and a demand that makes it the subject that it is, but which it cannot entirely fulfil. The sovereignty of my autonomy is always usurped by the heteronomous experience of the other's demand. The ethical subject is a dividual. ${ }^{8}$ (2007: 10-11)

In attending to the other's demand, a sense of dislocation and displacement also informs Barker's early attempt to "overcome the self", yet amidst the structures of confession and disavowal and especially in his cribbed confinement, it is also possible to discern a certain anxiety of influence in the opening to the book that secured his reputation. Pepys the navy clerk as a cipher for (and a rage against) traditional literary critics, writing and reading like Barker still within but also against the apparatus? Maybe all this is simply to say that from the earliest stage, Barker's own work always confronted the dilemma of critical finitude in situ, occupying a belated afterlife that always tried to remain responsive to the "ghostly mutterings" of that "involuted" speech which somehow resisted subordination. In this form, Barker's critical position also constituted a type of belonging in displacement and as such it was

\footnotetext{
${ }^{7}$ Again the register is from Blanchot as formulated by Haase and Large (2001: 71).

${ }^{8}$ Hetro-affectivity could be said to link poetry and its criticism to politics by confirming a profound disposition for dispossession. An ethical impulse which is reminiscent perhaps of Keats' sense of Shakespeare's "negative capability": a "sympathetic power of imagination" that is actually reliant on a form of "selfemptying" insofar as: "man [sic] is capable of being in uncertainties, mysteries, doubts, without any irritable reaching after fact and reason." In Keats' conception, the playwright's receptivity manifests an "excess of empathy" which is pitched against any restrictive tendency to abstract the facts of the matter. It is this ability to acknowledge the otherness of others that sets Shakespeare apart. See Letters of John Keats to his Family and Friends (1891: 48). I am grateful to Hartman (1996) for highlighting this connection to ethics.
} 


\section{J.J. Joughin}

entirely traditional in that it understood the openness of tradition as being itself "continually disrupted by the movement of writing and history" (cf. Haase and Large 2001: 118). And I will want to return to this sense of situatedness later on.

An unhealthy complicity between "Violence and Interpretation" (Barker 1993: 121-206) locates its fuller trajectory in Barker's later work in The Culture of Violence where in a memorable essay ${ }^{9}$ on Titus Andronicus he critiques the then new historicism as agnostically nonreflective concerning its own critical practice; a species of culturalism which merely aestheticises suffering and in the groundlessness of its interpretation fails to distinguish adequately between "aesthetic and fictional practices." The key passage comes halfway through the essay where Barker has cause to remark upon the unmotivated exit of the Clown:

This moment is stunning. The Clown is simply taken away to execution. Without cause given. We can speculate that the written "oration" the Clown delivers contains threats or curses, or that Saturninus interprets the knife wrapped in it as a symbolic offer of violence. But the point is that our interpretations would remain speculative. The emperor's action in ordering the Clown's death is inexplicable. Unexplained in the literal sense that no overt reason for it is given (and this is important because it contributes to the uncanniness of the incident), it is also unjustified in other senses. Not only does it lack credence according to the positive norms of behaviour the play assumes, but equally it fails to conform to the protocols of the deviations from those norms which the play more prominently foregrounds as the reality of Roman life: characters in Titus Andronicus may act "barbarously", but their behaviour is rarely random or arbitrary, on the contrary it is invariably ad hominem and selfishly purposeful [...] as a whole this brief episode remains entirely enigmatic and arbitrary. It is as if, running one's hand along a surface, something snags here. It is formally unmotivated in the sense of being aesthetically discrepant from the primitivism and the classicism of the rest of the play, and of lacking convincing preparation or legitimation in the thematic, narrative or hermeneutic codes of the text. It is inexplicable, as I have said, and never mentioned again. It is simply there: strange, unheimlich, and, I have found, haunting. (1993:167-168)

\footnotetext{
${ }^{9}$ See "A wilderness of tigers": 143-206.
} 
Here again, something unheimlich or spectral snags against the reading consciousness, tracing a "haunting that is history." Something disjoint or aesthetically discrepant applies, which traces an excess within representation itself related in turn to that which the text cannot represent more precisely perhaps it is "the transgression of the aesthetic" -in this case the formal aesthetic of classicism- "through the aesthetic." ${ }^{10}$

In the absent present of the play's afterlife, the death of the Clown confirms precisely the uneasy sense of writing and reading we have already had cause to notice. In this instance though, the exposure of the self to a form of non-justification (which is also, of course, in this case, the excessive demand of justice itself), might be said to be still more pressing, in that it presents us with these problems whilst also confronting us with somehow being presently involved (albeit at a distance) with these very same dilemmas. In performance it is as if the unendurable excess of bodies in extremis retains a sense of witness, for the audience that views them.

In the current instance the text is coy enough about its barbarism to spare us the spectacle, which for Barker at least only serves to make the excision more chilling. Here, and elsewhere in Barker's work, this seems to confirm a wry sense of Walter Benjamin's critique of the triumphal barbarism of culture itself, ${ }^{11}$ even as it registers the allegorical force of Benjamin's work The Origin of German Tragic Drama and his study of the baroque art of the Renaissance in the particular stage-form he terms Trauerspeil, or Mourning Play (1992). Not the least marvel of what Barker coins as early as The Tremulous Private Body the "glorious cruelties" of Jacobean drama is that here again finitude prevails, or, more accurately, it is as if this drama reminds us of that which we have chosen in our finite world to forget: precisely the constraints of finitude. As Barker infers, the unheimlich moment of such encounters inevitably serves to suggest that being-responsible is also paradoxically conjoint with not actually being-there. Indeed, in the case of the Clown's death, we are certainly in some profound sense

\footnotetext{
${ }^{10}$ Again I owe this formulation to Critchley (2007: 75).

${ }^{11}$ Cf. esp. the well known aphorism in Benjamin's "Theses on the Philosophy of history" that: "There is no document of civilization that is not at the same time a document of barbarism" (1968: 248).
} 


\section{J.J. Joughin}

not present. This too is the "truth of finitude", which prevails only insofar as, in the strictest sense, as Judith Butler reminds us: "the human is not identified with what is represented but neither is it identified with the unrepresentable; it is, rather, that which limits the success of any representational practice" (2006: 144). Furthermore, to be aware of these limits is also to be aware "of what is precarious in another life or, rather, the precariousness of life itself" (134).

\section{Memorial aesthetics}

Insofar as materialist and historicist criticism has remained fascinated with the hermeneutic yield provided by an allegorisation of the body in extremis, it has, as I have argued elsewhere (Joughin 2006a), re-enacted a type of "memorial aesthetics." This focus on the representation of dead bodies, or on images of their dismemberment "fresh bleeding", locates a paradigm-shift within the wider currents of cultural criticism itself, as, during the eighties and the nineties, we witnessed a shift from the "semantic to the somatic" -confirming, in some part, as Maurizio Calbi and Keir Elam have argued, a "reaction formation" against various brands of critical formalism that had hitherto prevailed, in order to confront what Elam refers to, as the: "irreducible and unrationalizable materiality" of "sheer untidy, asyntactic, pre-semantic bodliness" (Calbi 2001:13; and Elam cited in Calbi 2001: 13-14).

At its best, "radical thought" has illuminated the complex ways in which the history of modernity was itself compliant in the erasure, repression and supplementation of the body; and yet there are ways too, in which the recent affirmative corporeal "turn" of cultural criticism has also served to elide the political significance of a recovery of the importance of body, so that, as Terry Eagleton observes, despite the importance of this work: "a certain style of meditation on the body, on pleasures and surfaces, zones and techniques, has acted among other things as a convenient displacement of a less immediately corporeal politics, and acted also as an ersatz kind of ethics" (Eagleton 1990: 7). In short, there is, as Eagleton notes: "a privileged, privatised hedonism about such discourse, emerging as it does at just the historical point where certain less exotic forms of politics found themselves suffering a setback" (7). Within early variants of new historicism, suffering bodies regularly "staged history" and by doing so they became the 
alibi for a Foucauldian inspired "poetics of (Elizabethan) power" -in the process there is often an occlusion of the political and ethical implications of theatrical performance itself. Instead, in Barker's terms, in his critique of the new historicism, we are offered a "flattening out" of the ontological distinctions between theatre and society, as well as an oversimplification of the complex ways in which aesthetic and lived practices are inter-implicated in the process of informing our relation with others, both inside and outside the theatre (1993: 143-206).

The anguished complicities of Barker's work -its sense of present remove combined with troubled self-implication- locates an affinity in some of the work of the new historicism. Stephen Greenblatt for one is also "haunted" by the past and famously draws a comparison between the shaman and the literary critic for whom the critical act is curiously non-appropriative -for it is, as Derrida might say, "conditioned by the spectral" -a form of possession that dispossesses- not the critic's own voice but the voice of the other whose ghostly intensity is, Greenblatt informs us: "uncannily full of the will to be heard" (1988: 1). In continuing to speak with the dead in Hamlet in Purgatory (2001), Greenblatt goes still further, in pondering whether Shakespeare's theatre might itself be construed as a "cult of the dead" commenting that: "More than anyone of his age, Shakespeare grasped that there were powerful links between his art and the haunting of spirits" (2001: 258-261, 157). As if Shakespeare's theatre staged an elaborate "ontological argument", an exercise in "quasi-dying", where "the dead appear to live again" and in the same process revive contemporary theological debates concerning the status of suffrage and repentance (2001 passim).

In performance the dislocationary potential of this phantom-like economy of remembrance is simultaneously disconcerting and regenerative, and, however unsettling it proves to be, the restoration of the past can result in a "newly performed" openness to the unfulfillable demand of the other, as well as producing a newly evaluative understanding of the spectator's role in conceding the limits of their own historical situation. As such, in the process of resurrecting the dead, Shakespeare's theatre obviously has a direct role play in reconstituting and rehabilitating the transformative interaction of culture and memory. The ethical and political 


\section{J.J. Joughin}

implications of this hermeneutic encounter need to be interrogated and reconfigured in their relation to tragedy and history.

Again, for Barker, our own inability to conceive of the Renaissance body politic otherwise is already a mark of a considerable bourgeois forgetting, yet it also serves to witness a related affinity, as, despite its latter-day erasure and its present remove, the insistent materiality of the Jacobean corpus of Shakespeare and his contemporaries nevertheless retains its potential to light the poetic touch-paper:

The Jacobean body -the object, certainly, of terrible pressures- is distributed irreducibly through a theatre whose political and cultural centrality can only be measured against the marginality of the theatre today; and beyond the theatre it exists in the world whose most subtle inner organization is so different from that of our own not least because of the part played by the body in it. In the fullest sense of which it is now possible to conceive, from the other side of our own carnal guilt, it is a corporeal body, which, if it is already touched by the metaphysics of its later erasure, still contains a charge which, set off by the violent hands laid on it, will illuminate the scene, incite difference, and ignite poetry. This spectacular visible body is the proper gauge of what the bourgeoisie had to forget. (1984: 25)

In the performance of suffering, as Barker insinuates, there is a poetics, a pathos or 'charge' (maybe it is an obligation or a pleading in open "presence"?) that will repay further interrogation. Set off for Barker in this instance by violent hands (of interpretation no doubt) which will "illuminate the scene, incite difference, and ignite poetry."

Again, such moments also clearly activate an interpersonal notion of "readerly responsibility" in exposing us directly to what an ethical criticism, influenced by the readings of Levinas and Derrida, might term the infinite demand or "irreducible otherness of the other." Yet this demand for justice is distributed, as Barker himself puts it, "irreducibly throughout a theatre whose political and cultural centrality can only be measured against the marginality of the theatre today." Beyond its savage re-appropriation, beyond its appropriation of savagery itself, in the process of its recuperation as "our tradition", Jacobean poetry nonetheless ignites an ethical impulse which cannot be grounded by criticism, or much less located by its retrospective justification(s); but rather instead evokes 
a sense of unrelinquished belatedness: the felt need to bear a "last witness", an "“inspiring insomnia," ${ }^{12}$ which haunts liberal humanists and historicists alike.

As Simon Critchley argues, it is this "exorbitant demand which heteronomously determines the ethical subject" yet, in turn, as he points out: "I am not the equal of the demand that is made upon me [...] this explains why, for Levinas, the relation to the other is asymmetrical. That is, the subject relates itself to something that exceeds its relational capacity" (2007: 57). In short, as Critchley puts it, as a "dividuated self" the "ethical subject" is defined: "in terms of a split between itself and an exorbitant demand that it can never meet, the demand to be infinitely responsible [...] the subject shapes itself in relation to a demand that it can never meet, which divides and sunders the subject" (2007: 40).

As such, even as cultural materialism and new historicism could be said to have overturned conventional forms of tragic individualism in their readings of tragedy and history, the critical formation is still beset by a haunting form of tragic guilt which is difficult to bear, as if asking, in Critchley's terms: "How can I respond in infinite responsibility to the other without in turn extinguishing myself as a subject?" (2007: 69). Couched in these terms alone, the question of the dead remains unfulfillable. For how are we to eventually come to terms with the dead (and the living) and meet their demand, if their history is fated only to be construed as the figure of, and for, inconsolable loss? How are we to embrace the hyperbolic burden of the nameless undead?

\section{Lamentations}

In some sense, as I've already suggested, these remain the barely articulated yet key political questions that have haunted the work of materialist and historicist critics alike ever since. And if, in these circumstances, the fascination of much materialist historiography lies in tracing the erasure of corporeality, and in witnessing the simultaneous emergence of an uncanny sense of otherness concerning our own being; then it is precisely because the attraction of the body, and the manner in which our attempts to construe it are

${ }^{12}$ Again the register points to Blanchot. 


\section{J.J. Joughin}

exceeded (or takes us to the limit of representation), that the corpus of work that I am interrogating here traces the outline of something sublime. For, even as bourgeois history intrigues its disappearance, our body is also that which can never be laid to rest or closure. In short, it too constitutes a site that presents or expresses "a forever non-appearing inside, interiority, outside" -so that, as Jay Bernstein reminds us: "what cannot appear in itself, what cannot be made present (without the thought of its being simultaneously absent) is our autonomy" (1992: 23), or, as Hamlet famously puts it: "I have that within which passes show."

In other words, the ontological uncertainties of "hauntology"13 and those spectres that exceed embodiment paradoxically ensure the emergence of an equivocal "self-consciousness". A self, unsure of its "self", equally unsure of its knowledge of the existence of others. Yet paradoxically of course, on this, the terrifying brink of the body's disappearance, new figures and forms of authenticity are simultaneously required to overcome and combat the condition of actually being individuated, or modern. And within the discourses that attempt to rationalize, justify and politicise the emergence of an autonomous self, every attempt is made to counteract the concomitant alienation and solitude that our possession of this dubious "freedom" of individuality entails. This gives rise to what Jay Bernstein aptly labels the "aporia of autonomy" (Bernstein 1993). So that, as a direct result of its positioning within the philosophical discourse of modernity, the "self" which would do away with the body now also simultaneously strives to reincorporate that which is heteronomous to the self -the body, history, community- even as it (the self) continues to locate substantially new figures which acknowledge in their very excess, the failure of these attempted acts of incorporation. In turn, the failure to re-assimilate that which is lost or beyond self-assimilation gives rise to the despairing mournful thought which was our first regret and our necessary accomplice in initially turning away from and doubting the body. And so, on it goes...

This sense of inconsolable loss simultaneously invokes an earlier legacy of lament that pre-dates early modern drama. In Richard II for example, as Richard casts himself as a sacrificial victim

${ }^{13}$ To borrow Derrida's term, see Specters of Marx (1994). 
and invites us to "peer into heart of nothing" his appeal is already directly reminiscent of the radical reflexivity of an earlier Christian tradition, where the path to a "saving self-knowledge" simultaneously locates an increasing "bemusement" concerning the self, so that, as Augustine puts it in his Confessions: "I became a great riddle to myself" (Cited in Aers 1992: 182; cf. Taylor 1989: 131). As such, Richard's appeal is already curiously outmoded -reminiscent of the lyrical suffering evoked by antecedents of poetic subjectivity in sources as wide-ranging as hagiographic writing and courtly romance (also overlooked by cultural materialism) and especially in terms of the 'confessional Augustianism' of Petrarch and other poets (cf. Aers 1992 passim). In short, Shakespeare's "lamentable tragedy", Richard II, is a Passion play, where the legacy of an incomprehensible grief and the aporetic configuration of its interiority is entwined with the homilectic exemplum -we are confronted with the sublime alterity of our own being configured as the "inward beholding" of an external truth in which we now may acknowledge a share. In this respect, Richard's lyricism dramatises a process self-iconisation where Christological metaphors and allusions to sacrifice and martyrdom are painfully embodied in the act of performance itself:

I'll give my jewels for a set of beads;

My gorgeous palace for a hermitage;

My gay apparel for an almsman's gown;

My figur'd goblets for a dish of wood;

My sceptre for a palmer's walking staff;

My subjects for a pair of carved saints,

And my little kingdom for a little grave. $(3 \cdot 3 \cdot 147-153)$

In his insistent apprehension of bereavement Richard eventually settles for casting himself in terms of those future commemorative practices that will canonise his memory and by which his anonymity will simultaneously guarantee his legacy -as the impossible object of his own grief. ${ }^{14}$

In its inversion of the worldly and the spiritual, Richard's lamentation is reminiscent of Holbein's "painterly realism" -each grounding us in mortality. Yet the risk is that Richard's hyperbole will be taken literally, or rather as merely theatrical. Indeed, it is

\footnotetext{
${ }^{14}$ For a fuller and more detailed engagement with Richard II as Mourning Play, which I partly depend on here, see Joughin (2006b) and also $c f$. Joughin (2006a).
} 


\section{J.J. Joughin}

precisely in these terms that Richard is often accused by his sceptical latter-day critics of waxing too lyrical, his overt theatricalisation of grief drawing the accusation of improbability, the tears of a "player king" re-enacting the terms of what Freud would term a "hysterical" mourning -interminably immersed in sad events that "occurred long ago." Yet if the denial of Richard's grief by others only consolidates the process by which he is cast as irretrievable, it also offers an audience a position from which to redeem themselves. In short, the extent of Richard's over-dramatic isolation will in time also itself prove a measure or gauge of an audience's willingness to overcome their scepticism and to commit to the very rites of pilgrimage he demands and envisages.

\section{Inaugurated mourning?}

Yet as I have suggested living up to this demand is not easy. And the question still remains how might we configure these forms of mourning and incompletion otherwise? In following Critchley's recent work, I want to close by suggesting that the picture of human finitude is perhaps better approached as comic acknowledgement rather than tragic affirmation. In Critchley's terms this is equally an acknowledgement of both "the ubiquity of the finite and its ungraspability." But comedy, or maybe even the tragic-comic, simultaneously allow for a sense of reparation -one which allows the subject to bear the excessive burden of the ethical demand without that demand turning to mere melancholic entrapment, or hysterical morning. In brief elaboration one could to turn to the rites of memorial, if not of pilgrimage, that close Shakespeare's King Lear:

\section{EDGAR}

The weight of this sad time we must obey,

Speak what we feel, not what we ought to say.

The oldest hath borne most; we that are young

Shall never see so much, nor live so long.

Exeunt with a dead march. (5.3. 322-325)

The passage is, as critics have remarked, at the very least ambivalent, yet in suggesting that: 'we that are young / Shall never see so much, nor live so long', Edgar's speech is certainly earthbound in that it constitutes a reflection from within experience that inaugurates a degree of responsibility for those who come after. As if we need to live the conditionality of our inheritance, however fraught with 
difficulty that "living" might be. Perhaps a clue resides in the words of the obligation that precede the play's last testament?

The weight of this sad time we must obey,

Speak what we feel, not what we ought to say.

As Reg Foakes reminds us in his gloss on the line, there seems to be a conscious echo here of Lear's opening scene: "in 1.1, Goneril and Regan spoke dutifully what they ought to say" (Foakes in Shakepeare 1997: 392; Foakes's emphasis). But now we might notice that in closing there is also the more substantial temporal duty or "obedience", which precedes what we merely "ought" to say: "The weight of this sad time we must obey" -a duty, that is to say, which is beyond mere public duty, and one which arguably marks an ethical turning point in coming after but now lying beyond the empty rhetoric which attended the official investment of power and responsibility at the beginning of the play. The outcome is discordant, yet it also arguably re-marks the recognition that "the obligations imposed by the dead are the obligations we discover and re-negotiate in life ${ }^{15}$-a form of ethical demand that lives on in our day-to-day commitments and continues to inform our relations with others in its development beyond the confines of mere unredeemable lament and future pilgrimage. ${ }^{16}$

Rather than to hypostasise the experience of suffering or to universalise its significance, this would be to suggest that the facticity of suffering actually "makes a virtue out of limitation" and resides in an openness to corrigibility. Here the difference between thinking and saying cannot be merely anticipated, so that -as the philosopher Gillian Rose puts it: "To grow in love-ability is to accept the boundaries of oneself and others, while remaining vulnerable, woundable, around the bounds" (Rose 1995: 98) -an ability that Cordelia arguably exhibits from the start of the play. And, unlikely as it seems, a morsel of this sentiment still survives in the play's closing stanza, even after the enduring memory of her death at the end of the play. As a consequence, we are bound to acknowledge it,

\footnotetext{
${ }^{15}$ I borrow this formulation directly from Wendy Wheeler who makes use of it (1999: 78 ) in her discussion of Graham Swift's novel Last Orders. Though I should that both Wheeler and I are indebted in turn here to the work of the philosopher Gillian Rose see esp. Mourning Becomes the Law (1996).

${ }^{16}$ For a more detailed consideration of the rites of memory at the end of Lear which I partially draw on here and below see Joughin (2002).
} 


\section{J.J. Joughin}

for its obligation is an ob-ligature, a binding-up, or bond, to which we are still bound. ${ }^{17}$

Moreover these ties and bonds seem crucial to any realisation of a future that moves us beyond mourning, even as this process is simultaneously bound up in the transformative impact of its loss, which could not have been anticipated in advance (cf. Butler 2004: 21). So that as Judith Butler observes in attempting to answer the question "What makes for a grievable life?":

When we lose certain people, or when we are dispossessed from a place, or a community, we may simply feel that we are undergoing something temporary, that mourning will be over and some restoration of prior order will be achieved. But maybe when we undergo what we do, something about who we are is revealed, something that delineates the ties we have to others, that shows us that these ties constitute what we are, ties or bonds that compose us. It is not as if an " $\mathrm{I}$ " exists independently over here and then simply loses a "you" over there, especially if the attachment to "you" is part of what composes who "I" am. If I lose you, under these conditions, then I not only mourn the loss, but I become inscrutable to myself. Who "am" I, without you? When we lose some of these ties by which we are constituted, we do not know who we are or what to do. On one level, I think I have lost "you" only to discover that "I" have gone missing as well. At another level, perhaps what I have lost "in" you, that for which I have no ready vocabulary, is a relationality that is composed neither exclusively of myself nor you, but is to be conceived as the tie by which those terms are differentiated and related.

Many people think that grief is privatizing, that it returns us to a solitary situation and is, in that sense, depoliticizing. But I think it furnishes a sense of political community of a complex order, and it does this first of all by bringing to the fore the relational ties that have implications for theorizing fundamental dependency and ethical responsibility. If my fate is not originally or finally separable from yours, then the "we" is traversed by a relationality that we cannot easily argue against; or, rather, we can argue against it, but we would be denying something fundamental about the social conditions of our very formation

\footnotetext{
${ }^{17}$ Again I am grateful to Wheeler 1999 for pointing out the "tie" between obligation and ligature (76).
} 
[...]. Let's face it. We're undone by each other. And if we're not, we're missing something. (Butler 2004: 22-23; Butler's emphasis)

These questions are often explored, more or less directly, in many of Shakespeare's histories and tragedies, particularly when we are faced with acts of commemoration and mourning that are bound up in questions of political legacy. At the close of Romeo and Juliet for example, the tie "that binds us even as we are undone" appears as a form of obligation -in lieu of a dowry that is still in some part constitutes a form of gift:

\section{CAPULET}

O brother Montague, give me thy hand.

This is my daughter's jointure, for no more

Can I demand.

\section{MONTAGUE}

But I can give thee more.

For I will raise her statue in pure gold, That whiles Verona by that name is known, There shall no figure at such rate be set As that of true and faithful Juliet.

\section{CAPULET}

As rich shall Romeo's by his lady's lie, Poor sacrifices of our enmity! (5.3.296-304)

In this instance the exemplary force of "Romeo and Juliet" is founded less on the idealised symbolic merit or otherwise of the commemorative gold memorial (which for all its excess of signification remains an exorbitant figure a price too high to pay), but rather on their legacy of unsettling counterpoint, the impossible memory of each, and each other, dying and mourning before their time even whilst outliving the other. In effect, as Jacques Derrida suggests, in his wonderful aphoristic staging of Shakespeare's play, we are confronted with:

the theatre of the impossible: two people each outlive the other. The absolute certainty which rules over the duel (Romeo and Juliet is the mis-en-scène of all duels) is that one must die before the other. One of them must see the other die. To no matter whom, I must be able to say: since we are two, we know in an absolutely ineluctable way that one of us will die before the other. One of us will see the other die, one of us will live on, even if only for an 


\section{J.J. Joughin}

instant. One of us, only one of us, will carry the death of the other -and the mourning. It is impossible that we should each survive the other. That's the duel, the axiomatic of every duel, the scene which is most common and the least spoken of -or the most prohibited-concerning our relation to the other. Yet the impossible happens -not in "objective reality," which has no say here, but in the experience of Romeo and Juliet. And under the law of the pledge, which commands every given world. They live in turn the death of the other, for a time the contretemps of their death. Both are in mourning -and both watch over the death of the other, attend to the death of the other. Double death sentence. Romeo dies before Juliet, whom he has seen dead. They both live, outlive the death of the other. (Derrida 1992: 422)

As Derrida suggests, this impossible "theatre of double survival," and the lovers' untimely death, remarks a death sentence that is also in part a "pledge" or promise. As such, it is a type of survival, a form of hope against hope anticipated perhaps by Romeo's earlier premonition during 5.1 within a "strange dream" that opens a space for reanimation:

I dreamt my lady came and found me dead -

Strange dream that gives a dead man leave to think! -

And breathed such life with kisses in my lips

That I revived and was an emperor. (5.1.6-9)

Crucially, in the case of Lear and Romeo and Juliet, something will survive "between finitude and infinitude" that reveals the political ties of community, and begins the process of moving beyond mourning. Yet, unsurprisingly perhaps, in the face of interminable and inconsolable loss, for those that come after, the temptation is often to opt for the imposition of a more formal restoration of a prior order. However constrictive and unrelenting it might now seem to be, this is certainly "true" of Nahum Tate's well known imposed comedic ending to King Lear, which unwittingly secretes its own testament to provisionality and improvisation even as it strives to forget the fact of that which will not be forgotten. Interestingly, Tate's original Dedication to his adaptation of the play, actually hinges on its own admission of an impossible juggling act. In the course of defending his "New-modelling of this story [...] whereof I had no Ground in my Author" he protests that he was "wract with no small Fears for so bold a change," and although he locates his main justification for the "re-modelling" of the play in its 
performance, protesting the change "well received by the audience," he feels bound to add one further "theoretical" disclaimer:

Neither is it of so Trivial an Undertaking to make a Tragedy end happily, for 'tis more difficult to save than 'tis to Kill: The Dagger and Cup of Poison are always in Readiness; but to bring the Action to the last Extremity, and then by probable means to recover All, will require the Art and Judgement of a Writer, and cost him many a Pang in the Performance. (Tate 1992 (1681): 25-26)

Is it too fanciful to hear a trace of regretful overcompensation in Tate's account of his 'accomplishment'? In 'hindsight', perhaps the trick will be in preserving the spirit of Tate's ethical intuition -his acknowledgement that 'tis more difficult to save (or repair?) than 'tis to Kill'-against the formal reconciliation that he finally opts for. Yet the admission of 'probable means' remains improbable. Faced with discordancy Tate opts for resolution, but the trace of protestation "tis more difficult to save [...] to bring the Action to the last Extremity, and then by probable means to recover All'-almost saves Tate's wishful thinking as a wishful need, acknowledging a part of truth which exceeds his grasp yet remains tantalising within reach. I would want to re-style Tate's 'improvement' of Lear as a comedy finally recast as a drama of misrecognition, where to read Tate in the spirit of Gillian Rose reading Hegel: "the drama of misrecognition [...] ensues at every stage and transition of the work -a ceaseless comedy, according to which our aims and outcomes constantly mismatch each other, and provoke yet another revised aim, action and discordant outcome" (1996: 72). If we accept the comic possibility of the impossible recursion that admits that it is more difficult to save than it is to kill, even as Tate would rather save us from doing so, then it -the comic possibility - still potentially saves us. For then we uphold in hope against hope a form of "ceaseless comedy" against mere comic closure. And if we do not, we deny any attempt to imagine it otherwise.

\section{Conclusion}

There is no God to save us at the end of King Lear or, indeed, at the end game of Romeo and Juliet. Yet, in each play, even as they remark distinctly different types of political settlement, Shakespeare's tragiccomic endings and their acts of finitude invite us to "make a virtue out of limitation." What I have termed "critical finitude" marks a 


\section{J.J. Joughin}

form of situatedness that becomes creative and transformative precisely because, it is open to such renegotiation. In these terms many of the faultlines and rupture points of the "dissident criticism" of the eighties and nineties might well occupy the same terrain. As such, in the face of its apprehension of ruination, a critical subject encounters a type of limit -and yet experiences it as a form of situated ungrounding, which is simultaneously replete with the potential for new forms of productive mismatch between "aims and outcomes." In these terms, as Jay Bernstein reminds us "[s]elfreflection without transcendental reflection is the ethical act of self consciousness that brings the subject before and into his or her historical situation" (Bernstein 1992: 16), as well as his or her ties to others.

In these circumstances, the key question still perhaps remains "how to overcome authority without claiming authority." 18 For many cultural critics, as we have seen, this dilemma marks a form of "belonging in displacement" that creates a form of "politics as interstitial distance,"19 as critics work simultaneously within, and against, the state apparatus of which they are part -in Benjamin's terms "documents of civilisation" remain "documents of barbarism." Yet, only through living on after, surviving the confession of disaster and experiencing the guilt and self-implication of critical finitude, is it possible to surmount the self and conjure the possibility of reconciliation into being ( $c f$. Bernstein 1992: 16). Outside of melancholic encryptment, the experience of finitude, and our physical vulnerability, exposes the "relational ties to others" ( $c f$. Butler 2004: 22-23) that are implicit in any political sense of community. This, in turn, suggests a more sophisticated account of political subjectivity, as well as a potential reparation of the concept of a political self for radical criticism. Finally, as Judith Butler observes, faced with the sequence of "violence, mourning and politics":

Perhaps mourning has to do with agreeing to undergo a transformation (perhaps one should say submitting to a transformation) the full result of which one cannot know in advance. There is losing, as we know but there is also the

\footnotetext{
${ }^{18}$ Cf. n. 6 above.

${ }^{19}$ Again the phrase is borrowed from Critchley (2007: 111-114).
} 


$$
\text { (E) ederi } 19 \text { (2009) }
$$

transformative effect of loss, and this latter cannot be charted or planned. (2004: 21)

In these terms, we might usefully learn to live with the consequence and legacy of historical difference and incalculable loss, as well as recognising its potentially transformative affinities, in the process of rebuilding our political future.

\section{References}

Aers, David 1992. "A Whisper in the Ear of the Early Modernists; or, Reflections on Literary Critics Writing on the 'History of the Subject'." Ed. David Aers. Culture and History, 1350-1600: Essays on English Communities, Identities and Writings. Detroit: Wayne State University Press: 177-202.

Barker, Francis 1984. The Tremulous Private Body: Essays on Subjection. London: Methuen.

Barker, Francis 1993. The Culture of Violence: Tragedy and History. Manchester: Manchester University Press.

Belsey, Catherine 1985. The Subject of Tragedy: Identity and Difference in Renaissance Drama. London: Routledge.

Benjamin, Walter 1968. Illuminations. Ed. Trans. H. Zohn, introd. H. Arendt. London: Fontana.

Benjamin, Walter 1992 (1928). The Origin of German Tragic Drama. Trans. John Osborne. London: New Left Books.

Bernstein, Jay 1992. The Fate of Art: Aesthetic Alienation from Kant to Derrida and Adorno. Cambridge: Polity Press.

Bernstein, Jay 1993. "Autonomy and Solitude." Ed. Keith Ansell Pearson. Nietzsche and Modern German Thought. London: Routledge: 192-215.

Bernstein, Jay 2006. Against Voluptuous Bodies: Late Modernism and the Meaning of Painting. Stanford: Stanford University Press.

Bowie, Andrew 1997. From Romanticism to Critical Theory: The Philosophy of German Literary Theory. London: Routledge.

Bowie, Andrew 2003 (1990). Aesthetics and Subjectivity: From Kant to Nietzsche. Manchester: Manchester University Press.

Butler, Judith 2004. Precarious Life: The Powers of Mourning and Violence. London: Verso. 
Calbi, Maurizio 2001. Approximate Bodies: Aspects of the Figuration of Masculinity, Power and the Uncanny in Early Modern Drama and Anatomy. Salerno: Oedipus.

Carroll, John 1993. Humanism: The Wreck of Western Culture. London: Fontana Press.

Critchley, Simon 1998. "Introduction: What is Continental Philosophy." Ed. Simon Critchley and William $\mathrm{R}$ Schroeder. A Companion to Continental Philosophy. Oxford: Blackwell: 1-17.

Critchley, Simon 2007. Infinitely Demanding: Ethics of Commitment, Politics of Resistance. London: Verso.

Derrida, Jacques 1992 (1986). "Aphorism Countertime." Ed. Derek Attridge. Acts of Literature. London: Routledge: 414-433.

Derrida, Jacques 1994. Specters of Marx: The State of the Debt, the Work of Mourning, and the New International. Trans. P. Kamuf. London: Routledge.

Descartes, Rene 1986 (1641). Meditations on First Philosophy. Trans. J. Cottingham. Cambridge: Cambridge University Press.

Docherty, Thomas 1996. "Tragedy and the nationalist condition of criticism." Textual Practice 10/3: 479-505.

Dollimore, Jonathan 1989 (1984). Radical Tragedy: Religion, Ideology, and Power in the Drama of Shakespeare and his Contemporaries. Brighton: Harvester Wheatsheaf.

Eagleton, Terence 1990. The Ideology of the Aesthetic. Oxford: Basil Blackwell.

Foakes, R. A. 1997. "Introduction." Ed. R. A. Foakes. King Lear. Walton-onThames: Thomas Nelson and Sons Ltd, The Arden Shakespeare: 1-151.

Greenblatt, Stephen 1980. Renaissance Self-fashioning: From More to Shakespeare. Chicago: University of Chicago Press.

Greenblatt, Stephen 1988. Shakespearean Negotiations: The Circulation of Social Energy in Renaissance England. Oxford: Clarendon.

Greenblatt, Stephen 2001. Hamlet in Purgatory. Princeton: Princeton University Press.

Hartman, Geoffrey H. 1996. "Shakespeare and the Ethical Question." English Literary History 63: 1-23.

Haase, Ullrich and Large, William 2001. Maurice Blanchot. London: Routledge.

Joughin, John J. 2002. "Lear's Afterlife." Shakespeare Survey 55: 67-81.

Joughin, John J. 2006a. "Shakespeare's Memorial Aesthetics." Ed. Peter Holland. Shakespeare, Memory and Performance. Cambridge: Cambridge University Press: 43-62. 
Joughin, John J. 2006b. "Richard II and the Performance of Grief." Eds. Dermot Cavanagh, Stuart Hampton-Reeves and Stephen Longstaffe. Shakespeare's Histories and Counter-Histories. Manchester: Manchester University Press: 15-31.

Keats, John 1891. Letters of John Keats to his Family and Friends. Ed. by Sidney Colvin. London. Macmillan and Co.

Rorty, Richard 1989. Contingency, Irony and Solidarity. Cambridge: Cambridge University Press.

Rose, Gillian 1995. Love's Work. London: Chatto and Windus.

Rose, Gillian 1996. Mourning Becomes the Law: Philosophy and Representation. Cambridge: Cambridge University Press.

Shakespeare, William 1991. Richard II. Ed. by Peter Ure. London: Arden.

Shakespeare, William 1997. King Lear. Ed. by R. A. Foakes. Walton-onThames: Thomas Nelson and Sons Ltd, The Arden Shakespeare.

Shakespeare, William 1967. Romeo and Juliet. Ed. by T. J. B. Spencer. Harmondsworth: Penguin Books, The New Penguin Shakespeare.

Tate, Nahum 1992 (1681): "Dedication and Prologue to King Lear." Ed Frank Kermode. Shakespeare: King Lear. Basingstoke: Macmillan: 25-26.

Taylor, Charles 1989. Sources of the Self: The Making of Modern Identity. Cambridge: Cambridge University Press.

Wheeler, Wendy 1999. "Melancholic Modernity and Contemporary Grief: The Novels of Graham Swift." Ed. Roger Luckhurst and P. Marks. Literature and the Contemporary: Fictions and Theories of the Present. Harlow: Longman: 63-79.

How to cite this article:

Joughin, John J. “Dividuated selves: on Renaissance criticism, critical finitude and the experience of ethical subjectivity." SEDERI 19 (2009): 45-69.

Author's contact: JJoughin@uclan.ac.uk

Submission: 19/01/2009

Acceptance: 24/02/2009 